\title{
Improving the safety of cell therapy products by suicide gene transfer
}

\author{
Benjamin S. Jones ${ }^{1}$, Lawrence S. Lamb ${ }^{1}$, Frederick Goldman ${ }^{2}$ and Antonio Di Stasi ${ }^{1 *}$ \\ Bone Marrow Transplantation and Cellular Therapy Unit, Division of Hematology-Oncology, Department of Medicine, The University of Alabama at Birmingham, \\ Birmingham, AL, USA \\ ${ }^{2}$ Division of Hematology Oncology, Department of Pediatrics, The University of Alabama at Birmingham, Birmingham, AL, USA
}

\section{Edited by:}

Christophe Ferrand, Etablissement

Français du Sang Bourgogne

Franche-Comté/INSERM UMR1098,

France

\section{Reviewed by:}

Eric Robinet, Institut

Hospitalo-Universitaire de

Strasbourg, France

Martin Pule, University College

London, UK

${ }^{*}$ Correspondence:

Antonio Di Stasi, The University of

Alabama at Birmingham, 1824 6th

Avenue South, WT1520E

Birmingham, AL 35294, USA

e-mail: adistasi@uabmc.edu
Adoptive T-cell therapy can involve donor lymphocyte infusion after allogeneic hematopoietic stem cell transplantation, the administration of tumor infiltrating lymphocyte expanded ex-vivo, or more recently the use of $\mathrm{T}$ cell receptor or chimeric antigen receptor redirected $T$ cells. However, cellular therapies can pose significant risks, including graft-vs.-host-disease and other on and off-target effects, and therefore strategies need to be implemented to permanently reverse any sign of toxicity. A suicide gene is a genetically encoded molecule that allows selective destruction of adoptively transferred cells. Suicide gene addition to cellular therapeutic products can lead to selective ablation of gene-modified cells, preventing collateral damage to contiguous cells and/or tissues. The "ideal" suicide gene would ensure the safety of gene modified cellular applications by granting irreversible elimination of "all" and "only" the cells responsible for the unwanted toxicity. This review presents the suicide gene safety systems reported to date, with a focus on the state-of-the-art and potential applications regarding two of the most extensively validated suicide genes, including the clinical setting: herpes-simplex-thymidine-kinase and inducible-caspase-9.

Keywords: suicide gene, cell therapy, iCasp9, CAR T cells, TCR redirected T cells, HSV-tk

\section{INTRODUCTION}

Adoptive T-cell therapy can involve donor lymphocyte infusion (DLI) after allogeneic hematopoietic stem cell transplantation (allo-HSCT) (Copelan, 2006; Bar et al., 2013), the administration of tumor infiltrating lymphocyte (TILs) expanded ex-vivo (Dudley et al., 2013), or more recently the use of T cell receptor (TCR) or chimeric antigen receptor (CAR) redirected $\mathrm{T}$ cells (Cieri et al., 2014).

Cellular therapies are not without risks. Donor T cells within the HSC product or infused post-transplant as DLI have been associated with potentially fatal graft-vs.-host-disease (GVHD) (Copelan, 2006), whereas administration of engineered $\mathrm{T}$ cells has also resulted in on/off target toxicities as well as a cytokine release syndrome (Tey, 2014).

Unlike small molecules or biologics, cell therapies have a very long, or even an indefinite half-life, therefore since toxicity can be progressive a safety switch is needed in order to eliminate the infused cells in case of adverse events. A suicide gene is a genetically encoded molecule that allows selective destruction of adoptively transferred cells. Suicide gene addition to cellular therapeutic products can lead to selective ablation of gene-modified cells, preventing collateral damage to contiguous cells and/or tissues. The "ideal" suicide gene would ensure the safety of gene modified cellular applications by granting irreversible elimination of "all" and "only" the cells responsible for the unwanted toxicity.

This review presents the suicide gene safety systems reported to date, with a focus on the state-of-the-art and potential applications regarding two of the more extensively validated suicide genes in the clinical setting: herpes-simplex-thymidinekinase (HSV-TK) and inducible-caspase-9 (iCasp9).

\section{AVAILABLE SUICIDE GENE TECHNOLOGIES}

Suicide gene technologies can be broadly classified based upon their mechanism of action in metabolic (gene-directed enzyme prodrug therapy, GDEPT), dimerization inducing, and therapeutic monoclonal antibody mediated. The ideal agent for suicide gene activation should be biologically inert, have an adequate bioavailability and bio-distribution profiles, and be characterized by intrinsic acceptable or absent toxicity.

GDEPT (Springer and Niculescu-Duvaz, 2000) converts a nontoxic drug to a toxic compound in gene-modified cells. Examples include herpes simplex virus thymidine kinase (HSVTK) (Ciceri et al., 2007, 2009), and cytosine deaminase (CD) (Tiraby et al., 1998). Unlike the mammalian thymidine kinase, HSV-TK is characterized by 1000 fold higher affinity to specific nucleoside analogs (Elion et al., 1977), including ganciclovir (GCV), making it suitable for use as a suicide gene in mammalian cells. Mechanistically, HSV-TK phosphorylates nucleoside analogs, including acyclovir and GCV, and their resulting triphosphate form incorporates into DNA via the action of DNA polymerase, leading to chain termination and cell death (Moolten, 1986). HSV-TK/GCV also induces apoptosis through CD95-L independent CD95 aggregation, leading to the formation of a Fas-associated death domain protein (FADD) 
and caspase-8-containing death-inducing signaling complex (Beltinger et al., 1999). Similarly, the CD gene encodes cytosine deaminase, which converts 5-fluorocytosine (5-FC) into the cytotoxic 5-fluorouracil (5-FU) (Tiraby et al., 1998).

Apoptotic genes (e.g., Caspases) eliminate cells by inducing apoptosis (Yamabe et al., 1999; Carlotti et al., 2005; Di Stasi et al., 2011; Zhou et al., 2014). Chimeric proteins composed of a drug binding domain linked in frame with components of the apoptotic pathway allow conditional dimerization and apoptosis of the transduced cells after administration of a non-therapeutic small molecule dimerizer (Belshaw et al., 1996; Spencer et al., 1996; MacCorkle et al., 1998; Straathof et al., 2005). Examples include the inducible FAS (iFAS) or inducible Caspase9 (iCasp9)/AP1903 systems (Clackson et al., 1998; Di Stasi et al., 2011).

Genetic modification of cells with a protein expressed in the plasma membrane (Hewitt et al., 2007), allows cell removal after administration of a specific monoclonal antibody. For example, retroviral delivery of the CD20 molecule into $\mathrm{T}$ cells and antiCD20 monoclonal antibody treatment post $\mathrm{T}$ cell infusion has been validated in preclinical models as a suicide gene strategy (Introna et al., 2000; Serafini et al., 2004; Griffioen et al., 2009). As an extension of this concept, other interesting pre-clinical models have been investigated: Kieback et al. introduced a 10 amino acid tag of c-myc protein into the TCR sequence allowing elimination after monoclonal antibody administration (Kieback et al., 2008), whereas a group from London generated a novel compact suicide gene (RQR8) combining epitopes from CD34 and CD20 enabling CD34 selection, cell tracking, as well as deletion after anti-CD20 monoclonal antibody administration (Philip et al., 2014), and finally, another approach has used truncated human EGFR polypeptide/anti-EGFR monoclonal antibody (Wang et al., 2011).

The mechanisms of action for the different suicide gene families is depicted in Figure 1, and characteristics of the major suicide gene systems investigated to date for adoptive immunotherapy are listed in Tables 1, 2.

The effectiveness of four suicide gene strategies has been compared in vitro using Epstein Barr virus cytotoxic T cells genetically modified to express HSV-TK, iCasp9, mutant human thymidylate kinase (mTMPK), or human CD20 codon optimized suicide gene. In this study, activation of HSV-TK, iCasp9, and CD20 ultimately resulted in equally effective destruction of transduced T cells. However, while iCasp9 and CD20 effected immediate cell-death induction, HSV-TK-expressing T cells required 3 days of exposure to ganciclovir to reach full effect, and mTMPKtransduced cells showed lower T-cell killing at all time-points (Marin et al., 2012).

Currently a one size fits all suicide gene is yet to be identified. The best suicide gene strategy should be designed for each specific application, taking into consideration the nature of target cells, the source of the suicide gene, the type of activating agent, the onset of action, and the elimination's kinetic of the target population.

Pre-clinical and clinical data employing the iCasp9 suicide gene system showed preferential elimination of cells with high iCasp9 transgene expression with sparing of quiescent cells. While this can represent an advantage when used for DLI, sparing viral and fungal reactive T cells (Zhou et al., 2014), complete elimination of CAR/TCR redirected T cells or HSCs may be necessary for the adverse event to abate. Therefore selection of cells with bright transgene expression, or combination of two suicide genes is advisable. Several strategies can be employed to ensure that all the "gene corrected" cells harbor the suicide gene. Cells may be transduced with a bicistronic vector with the suicide gene before an IRES or 2A sequence, or alternatively a selection strategy is used with introduction of a selectable marker.

The source of the suicide gene is also an important component of the strategy design. For example, in contrast to the iCasp9 suicide gene almost completely human derived, viral derived systems, such as HSV-TK, proved immunogenic in immunecompetent patients with limited persistence of HSV-TK cells (Traversari et al., 2007).

Activating agents can also have varying effects, affecting the choice of which suicide gene system utilize for a given application. For example, AP1903 is a biologically inert small molecule dimerizer, whereas ganciclovir can also be used as a therapeutic agent to treat cytomegalovirus reactivation, precluding its use in patients receiving HSV-TK modified cells. The use of therapeutic monoclonal antibodies, in case of CD20 suicide gene or other surface markers, can lead to on-target effects. Therefore the adoption of molecules/antibodies with low toxicity profiles are preferred. Rapid onset of action of iCasp9 may be preferred to shut down a potentially fatal GVHD event. However a more gradual onset of action might be preferred to preserve a graft versus tumor effect.

Finally, resistance mechanisms can develop with these new technologies, and GCV-resistant truncated HSV-TK forms have been observed (Garin et al., 2001).

Currently, only HSV-TK/GCV and iCasp9/AP1903 have entered clinical trials to enhance the safety of cellular therapeutics for hematologic malignancies.

\section{CLINICALLY VALIDATED SUICIDE GENES FOR CONTROL OF GVHD}

Two suicide genes have been validated in the clinic for control of GVHD from administration of donor T cells after HSCT in an effort to enhance immune recovery and maximize graft-vs.leukemia (GVL) effect: the iCasp9 and the HSV-TK suicide genes. Clinical results are summarized in Table 3.

\section{HSV-TK SUICIDE GENE}

Bonini et al. demonstrated the efficacy of HSV-TK suicide gene modified T cells in controlling GVHD in 8 patients who received DLI after HSCT for disease relapse or EBV post-transplant lymphoproliferative disease (PTLD). Importantly, a GVL effect attributed to the DLI was demonstrated in five patients (Bonini et al., 1997).

Subsequently, Tiberghien reported on 12 patients with hematologic malignancies who underwent HLA-matched related donor allo-HSCT (Tiberghien et al., 2001), and received HSV-TK DLI on the day of transplantation. Treatment with GCV alone resulted in complete remission (CR) in two of the three patients with aGVHD and CR was achieved with the addition of steroids in the third. GCV treatment also resulted in CR for the patient with cGVHD (Tiberghien et al., 2001). 


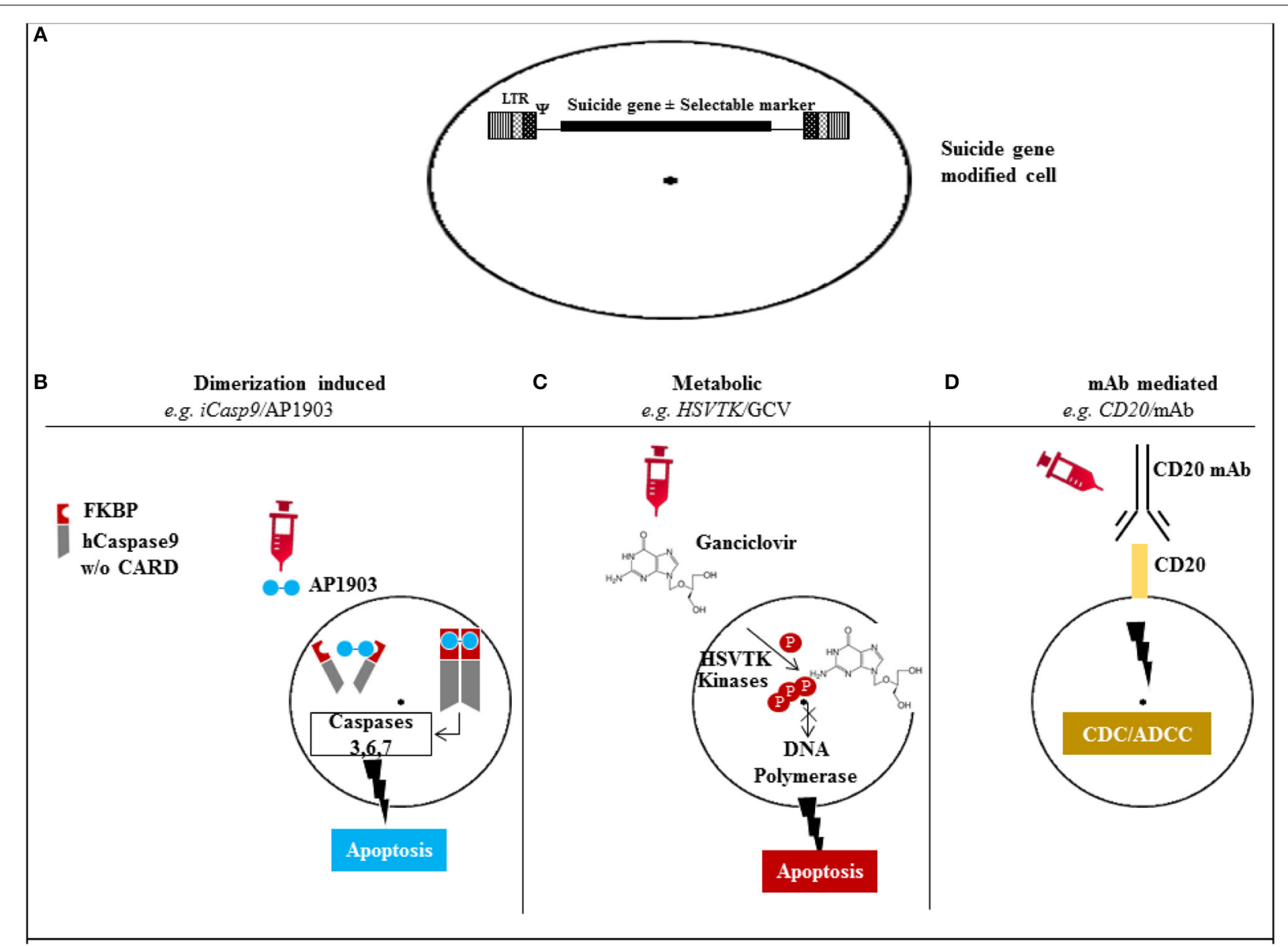

FIGURE 1 | Mechanism of action of the different suicide gene technologies. (A) Suicide gene modification of cells of interest to allow conditional elimination in case of serious adverse events. Surface marker suicide genes, e.g., CD20, can also function as a selectable marker. (B) Dimerization induced e.g., iCasp9 protein with FKBP12-F36V binding domain joined to human caspase-9. Administration of AP1903 leads to dimerization of iCasp9 activating the intrinsic mitochondrial apoptotic pathway. (C) Metabolic, e.g., HSV/TK leads to phosphorylation of ganciclovir, and its triphosphate form (phosphorylated also through cellular kinases) incorporates into DNA with chain termination. (D) Monoclonal antibody (mAb) mediated, e.g., CD20 overexpression allows elimination after exposure to CD20 mAb through complement/antibody dependent cellular cytotoxicity (CDC/ADCC). LTR: long terminal repeat, psi: retroviral packaging element, iCasp9: inducible Caspase9, CARD: Caspase recruitment domain, HSVTK: herpes simplex virus thymidine kinase, GCV: ganciclovir, mAb: monoclonal antibody.
The anti-tumor effects of HSV-TK DLI was studied in 23 patients with relapsed hematologic malignancies (Oliveira et al., 2012), where a clinical benefit was demonstrated in $65 \%$ of the cases. The development of antibodies against HSVTK did not preclude a GVL effect, as the patients remained in complete remission thereafter, possibly due either to survival of a low $\mathrm{T}$ cell number in the periphery sufficient for immune surveillance, or abrogation of minimal residual disease. Eventually, the gradual elimination of HSV-TK cells can also contribute to a protracted GvL effect. GVHD was successfully controlled abrogated by the safety switch in this trial, as well (Traversari et al., 2007). Of note, infused $\mathrm{T}$ cells persisted in vivo up to 14 years after infusion (Oliveira et al., 2012). The largest study with 28 patients receiving HSV-TK engineered DLI after $\mathrm{T}$ cell depleted haplo-HSCT was published in 2009 (Ciceri et al., 2009). GVHD was successfully controlled with daily GCV administered for 2 weeks, with no cases of GCV resistance, progression from acute to chronic GVHD, and no GVHD-associated deaths. For patients with primary acute leukemia transplanted in remission the nonrelapse mortality at 3 years was $19 \%$. All patients in remission 3 years after transplant remained so in the following years (longest follow up 9 years) (Ciceri et al., 2009; Oliveira et al., 2012) Additional indirect evidence suggesting a GVL effect was the finding of de novo loss of mismatched HLA expression on leukemic blasts in one patient at the time of relapse (Vago et al., 2009).

\section{iCasp9 SUICIDE GENE}

Spencer et al. (1993) and Clackson et al. (1998) demonstrated the ability to control signaling pathways through the administration of lipid permeable synthetic ligands, inducing 
Table 1 | Comparison of suicide genes for adoptive immunotherapy.

\begin{tabular}{|c|c|c|c|c|c|}
\hline Category & Technology & Source & $\begin{array}{l}\text { Activating } \\
\text { agent }\end{array}$ & Mechanism(s) & References \\
\hline \multirow[t]{2}{*}{ Metabolic } & HSV-TK & Virus & GCV & $\begin{array}{l}\text { 1. Phosphorylated nucleotide } \\
\text { disrupts DNA with cell death; } \\
\text { 2. Apoptosis }\end{array}$ & $\begin{array}{l}\text { Moolten, 1986; Bonini et al., } \\
\text { 1997; Tiberghien et al., 2001; } \\
\text { Ciceri et al., 2007, 2009; Vago } \\
\text { et al., 2009; Oliveira et al., } 2012\end{array}$ \\
\hline & $C D$ & Bacteria,fungi & $5-\mathrm{FC}$ & $\begin{array}{l}\text { Conversion of 5-FC to cytotoxic } \\
5-\mathrm{FU}\end{array}$ & Tiraby et al., 1998 \\
\hline \multirow[t]{2}{*}{ Dimerization inducing } & iFAS & Human & $\begin{array}{l}\text { Small molecule } \\
\text { dimerizer }\end{array}$ & $\begin{array}{l}\text { Dimerization and induction of } \\
\text { apoptosis }\end{array}$ & Spencer et al., 1996 \\
\hline & iCasp9 & Human & As above & As above & $\begin{array}{l}\text { Spencer et al., 1993; Clackson } \\
\text { et al., 1998; Di Stasi et al., 2011; } \\
\text { Zhou et al., } 2014\end{array}$ \\
\hline & c-myc & Human & Anti-cmyc & As above & Kieback et al., 2008 \\
\hline & EGFR & Human & Anti-EGFR & As above & Wang et al., 2011 \\
\hline
\end{tabular}

Legend: HSV-TK, herpes simplex virus thymidine kinase; GCV, ganciclovir; CD, cytosine deaminase; 5-FC, 5-fluorocytosin; 5-FU, 5-fluorouracil; iFAS, inducible FAS; iCasp9, inducible Caspase9; mAb, monoclonal antibody; EGFR, Epidermal growth factor receptor.

Table 2 | Pros and cons of suicide gene technologies.

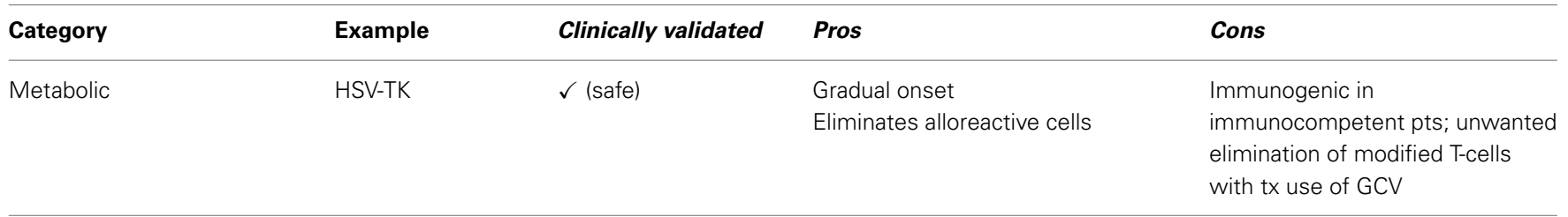

\begin{tabular}{|c|c|c|c|c|}
\hline Dimerization inducing & iCasp9 & $\checkmark$ (safe) & $\begin{array}{l}\text { Rapid onset } \\
\text { Eliminates alloreactive cells } \\
\text { Non Immunogenic } \\
\text { Use non-therapeutic agent }\end{array}$ & $\begin{array}{l}\text { Incomplete elimination, although } \\
\text { of } \geq 90 \% \text { of cells }\end{array}$ \\
\hline Therapeutic mAb mediated & $\begin{array}{l}\text { Surface } \\
\text { molecule (e.g. } \\
\text { CD20) }\end{array}$ & $\boldsymbol{x}$ (not validated) & $\begin{array}{l}\text { Rapid onset } \\
\text { Non immunogenic } \\
\text { No additional selectable marker } \\
\text { required }\end{array}$ & On-target toxicity from mAb \\
\hline
\end{tabular}

Legend: HSV-TK, herpes simplex virus thymidine kinase; GCV, ganciclovir; iCasp9, inducible Caspase9; tx, therapeutic.

conditional dimerization of intracellular proteins. They generated an inducible Casp9 suicide gene consisting of FKBP12-F36V domain linked, via a flexible Ser-Gly-Gly-Gly-Ser linker, to $\triangle$ Caspase 9, which is Caspase without its Caspase activator recruitment domain (Straathof et al., 2005). FKBP12-F36V consists of a FKBP domain with a substitution at residue 36 of phenylalanine for valine, binding synthetic dimeric ligands, such as AP1903 (Iuliucci et al., 2001), with high selectivity and subnanomolar affinity. The transgenic cassette was redesigned later to include a truncated CD19 ( $\triangle C D 19)$ molecule, serving as selectable marker to ensure $\geq 90 \%$ purity (Zhou et al., 1991; Fujimoto et al., 1998; Tey et al., 2007). After preclinical validation (Straathof et al., 2005; Tey et al., 2007), Brenner and collaborators reported their early results of a phase I clinical trial using the iCasp9 system (Di Stasi et al., 2011). Recipients of CD34-selected haplo-HSCT for hematological malignancies received escalating doses of iCasp9-modified allo-depleted (Amrolia et al., 2006; Tey et al., 2007) T cells from day 30 onwards. The iCasp9modified $\mathrm{T}$ cells expanded and persisted for at least two years in surviving patients. In four patients who developed aGVHD the administration of $0.4 \mathrm{mg} / \mathrm{kg}$ AP1903 resulted in apoptosis of $\geq 90 \%$ of iCasp9-modified T cells within $30 \mathrm{~min}$, followed by the rapid (within $24 \mathrm{~h}$ ) and permanent abrogation of GVHD. Remarkably, residual iCasp9-modified $\mathrm{T}$ cells were able to reexpand, contained pathogen-specific precursors, without further GVHD. Although T cells recognizing tumor-associated antigens 
Table 3 | Larger studies of suicide gene modified donor lymphocyte infusion.

\begin{tabular}{|c|c|c|c|c|c|c|c|}
\hline Graft & $\begin{array}{l}\text { Disease } \\
\text { status (N) }\end{array}$ & $\begin{array}{l}\text { Suicide } \\
\text { gene (N) }\end{array}$ & Relapse N & $\begin{array}{l}\text { N (aGVHD; } \\
\text { response) }\end{array}$ & $\begin{array}{l}\text { N (cGVHD; } \\
\text { response) }\end{array}$ & $\begin{array}{l}\mathrm{N}, \text { Clinical } \\
\text { response }\end{array}$ & References \\
\hline TCD-Haplo & $\begin{array}{l}\mathrm{CR}(9) \\
\operatorname{AD}(1)\end{array}$ & iCasp9 (10) & 4 & $4(\mathrm{CR})$ & 0 & $5 \mathrm{CCR}$ & $\begin{array}{l}\text { Di Stasi et al., 2011; } \\
\text { Zhou et al., } 2014\end{array}$ \\
\hline N/A & Relapse or EBV-PTLD (8) & HSV-TK (8) & N/A & 2 (CR) & $1(\mathrm{PR})$ & $3 \mathrm{CR}, 2 \mathrm{PR}$ & Bonini et al., 1997 \\
\hline TCD-MRD & $\begin{array}{l}A D(5) \\
C R(3) \\
C P(4)\end{array}$ & HSV-TK (12) & 2 & $5 ; C R 3 / 5$ & $1(\mathrm{CR})$ & 4 (CR/CCR) & Tiberghien et al., 2001 \\
\hline MRD, MMRD & Relapse (30) & HSV-TK (23) & N/A & $4(\mathrm{CR})$ & 1 (clinical benefit) & $6 \mathrm{CR}, 5 \mathrm{PR}$ & Ciceri et al., 2007 \\
\hline TCD-Haplo & $\begin{array}{l}\text { AD (20) } \\
C R(30)\end{array}$ & HSV-TK (28) & 17 & $10(\mathrm{CR})$ & $1(\mathrm{CR})$ & $5 \mathrm{CR}, 11 \mathrm{CCR}$ & Ciceri et al., 2009 \\
\hline
\end{tabular}

Legend: GVHD, graft-versus-host-disease; a, acute; c, chronic; N, number; TCD, T cell depleted; haplo, 5/10 HLA matched haploidentical; (C)CR, (continuous) complete remission; AD, active disease; iCasp9, inducible Caspase9; D, day(s); EBV-PTLD, Epstein-Barr virus post-transplant lymphoproliferative disease; HSV-TK, herpes simplex virus thymidine kinase; NA, not available/applicable; PR, partial response; (M)MRD, (mis)matched related donor; CP, chronic phase.

(TAAs) could be reactivated ex vivo from the peripheral blood before and after AP1903 infusion, three of the four patients receiving AP1903 had disease relapse, compared to only one of six patients who were not so treated, raising the concern that elimination of alloreactive cells would hamper GVL (Zhou et al., 2014), because of the potential co-expression of minor histocompatibility antigens on hematopoietic and non-hematopoietic tissues (de Bueger et al., 1992; Wang et al., 1995; Meadows et al., 1997; Vogt et al., 2000). The relative contribution of alloreactive cells, as compared with TAAs specific $\mathrm{T}$ cells is not difficult to quantify, however since most TAAs are aberrantly expressed self-proteins resulting in T cells with low-affinity TCR, it is possible that the alloreactive component is more determinant for GvL. Additionally, although low frequency TAA specific $\mathrm{T}$ cells are transferred to patients after allo-HSCT or DLI, they do not persist (Rezvani et al., 2005, 2007), potentially due to activation-induced apoptosis (Molldrem et al., 2003), or terminally differentiated effector memory phenotype (Brenchley et al., 2003).

Given the successful abrogation of GVHD in vivo, several ongoing clinical trials have replaced the time consuming in vitro allo-depletion step with in vivo allo-depletion using AP1903 for those developing GVHD in the haploidentical (Clinicaltrials.gov identifier NCT01494103; NCT02065869; NCT01744223), or matched related settings, (Clinicaltrials.gov identifier NCT01875237).

In both the HSV-TK and iCasp9 studies, infusion of suicide gene modified cells aided non-gene modified $\mathrm{T}$ cell immune reconstitution (Ciceri et al., 2009; Bondanza et al., 2011; Di Stasi et al., 2011), as a consequence of interleukin-7 secretion by gene modified cells (Vago et al., 2012). The lack of further aGVHD in these studies might suggest either (i) complete elimination of allo-reactive cells, or (ii) development of peripheral tolerance. Additionally, the incidence of cGvHD was low in the HSV-TK $\mathrm{T}$ cell studies, and absent in the iCasp9 trial (Di Stasi et al., 2011; Zhou et al., 2014), and lymphocytes recovering from infused HSCs did not cause GVHD likely because of thymic education (Vago et al., 2012).

\section{SUICIDE GENES APPLICATION FOR THE SAFETY OF GENETICALLY REDIRECTED T CELLS}

TCR (Robbins et al., 2011) or CAR redirected T cells (Porter et al., 2011; Kochenderfer et al., 2012; Brentjens et al., 2013) have been successful implemented in several clinical trials. However adverse events including autoimmunity or off-target effects have been reported. Autoimmune phenomena manifested because the targeted antigens was shared also on normal tissues, (Yee et al., 2000; Dudley et al., 2002; Johnson et al., 2009; Parkhurst et al., 2011; Morgan et al., 2013) whereas off-target cardiac toxicity after high-avidity MAGE-A3 TCR T cells infusion was attributed to cross-reactivity with the Titin peptide in the striated muscles (Linette et al., 2013). Other toxicities observed included cytokine release syndrome (Brentjens et al., 2010; Kochenderfer et al., 2012), organ damage, including a case of fatal acute lung injury (Lamers et al., 2006, 2013; Morgan et al., 2010), and hypogammaglobulinemia from depletion of normal B cells (Kochenderfer et al., 2012). Although strategies including gamma globulin replacement, high dose corticosteroids, or the interleukin 6 receptor blocking antibody, tocilizumab exist for the management of hypogammaglobulinemia or cytokine release (Grupp et al., 2013; Davila et al., 2014), the use of a suicide gene is potentially able to irreversibly abrogate such toxicities. Pre-clinical experiments expressing the iCasp9 in conjunction with CAR CD19/CD20 T cells have proven the feasibility of such approach (Hoyos et al., 2010; Budde et al., 2013), and a phase 1 clinical trials in patients with sarcoma or neuroblastoma receiving iCasp9 $\mathrm{T}$ cells co-expressing a CAR against disialoganglioside GD2 molecule is ongoing (Clinicaltrials.gov identifier NCT01822652 and NCT01953900, respectively). If toxicity is related to the transduced $\mathrm{T}$ cells only, selectable markers could be obviated, especially in an autologous setting, provided that all the transduced cells also harbored the suicide gene in order to be eliminated in case of serious adverse events.

\section{CONCLUSIONS}

Innovative technologies offer compelling opportunities for the optimization of gene therapy based approaches. Successful clinical validation of suicide gene strategies to control GVHD after 
allo-HSCT is now in advanced phase clinical studies, and introduction of suicide genes in conjunction with CAR modification of $\mathrm{T}$ cells for cancer immunotherapy is now undergoing phase 1 clinical testing.

Suicide genes have also been employed as cytotoxic strategy, in vitro and in vivo models (Huber et al., 1991; Clark et al., 1997; Nor et al., 2002; Nakayama et al., 2005; Hodish et al., 2009; Evans and Dey, 2011; Duarte et al., 2012; Mazor et al., 2012), including combination with replication competent oncolytic viruses (Ahn et al., 2009; Kaur et al., 2009), with some evidence of clinical benefit in solid tumors (Pandha et al., 1999; Freytag et al., 2003, 2007; Nemunaitis et al., 2003; Voges et al., 2003; Li et al., 2007; Xu et al., 2009).

Finally, non-integrating vectors (Banasik and McCray, 2010), strategies for the replacement or correction of defective genes (Narsinh et al., 2011; Mukherjee and Thrasher, 2013; Li et al., 2014), together with effective suicide gene strategies, may lead to a more broad application of stem cell or inducible pluripotent stem cell based applications in cancer and regenerative medicine.

\section{AUTHOR CONTRIBUTIONS}

All the authors contributed to conception, acquisition, and analysis of data, participated in the manuscript draft preparation, revision and approved and revised the final version.

\section{ACKNOWLEDGMENT}

We are thankful to Dr. Ayman Saad for critically revising the final version of the manuscript.

\section{REFERENCES}

Ahn, M., Lee, S. J., Li, X., Jimenez, J. A., Zhang, Y. P., Bae, K. H., et al. (2009). Enhanced combined tumor-specific oncolysis and suicide gene therapy for prostate cancer using M6 promoter. Cancer Gene Ther. 16, 73-82. doi: 10.1038/cgt.2008.59

Amrolia, P. J., Muccioli-Casadei, G., Huls, H., Adams, S., Durett, A., Gee, A., et al. (2006). Adoptive immunotherapy with allodepleted donor T-cells improves immune reconstitution after haploidentical stem cell transplantation. Blood 108, 1797-1808. doi: 10.1182/blood-2006-02-001909

Banasik, M. B., and McCray, P. B. Jr. (2010). Integrase-defective lentiviral vectors: progress and applications. Gene Ther. 17, 150-157. doi: 10.1038/gt.2009.135

Bar, M., Sandmaier, B. M., Inamoto, Y., Bruno, B., Hari, P., Chauncey, T., et al. (2013). Donor lymphocyte infusion for relapsed hematological malignancies after allogeneic hematopoietic cell transplantation: prognostic relevance of the initial CD3+ T cell dose. Biol. Blood Marrow Transplant. 19, 949-957. doi: 10.1016/j.bbmt.2013.03.001

Belshaw, P. J., Spencer, D. M., Crabtree, G. R., and Schreiber, S. L. (1996). Controlling programmed cell death with a cyclophilin-cyclosporin-based chemical inducer of dimerization. Chem. Biol. 3, 731-738. doi: 10.1016/S10745521(96)90249-5

Beltinger, C., Fulda, S., Kammertoens, T., Meyer, E., Uckert, W., and Debatin, K. M. (1999). Herpes simplex virus thymidine kinase/ganciclovir-induced apoptosis involves ligand-independent death receptor aggregation and activation of caspases. Proc. Natl. Acad. Sci. U.S.A. 96, 8699-8704. doi: 10.1073/pnas.96.15.8699

Bondanza, A., Hambach, L., Aghai, Z., Nijmeijer, B., Kaneko, S., Mastaglio, S., et al. (2011). IL-7 receptor expression identifies suicide geneâ $€$ "modified allospecific CD8+ T cells capable of self-renewal and differentiation into antileukemia effectors. Blood 117, 6469-6478. doi: 10.1182/blood-2010-11-320366

Bonini, C., Ferrari, G., Verzeletti, S., Servida, P., Zappone, E., Ruggieri, L., et al. (1997). HSV-TK gene transfer into donor lymphocytes for control of allogeneic graft-versus-leukemia. Science 276, 1719-1724. doi: 10.1126/science.276.5319.1719

Brenchley, J. M., Karandikar, N. J., Betts, M. R., Ambrozak, D. R., Hill, B. J., Crotty, L. E., et al. (2003). Expression of CD57 defines replicative senescence and antigen-induced apoptotic death of CD8+ T cells. Blood 101, 2711-2720. doi: 10.1182/blood-2002-07-2103

Brentjens, R. J., Davila, M. L., Riviere, I., Park, J., Wang, X., Cowell, L. G., et al. (2013). CD19-targeted T cells rapidly induce molecular remissions in adults with chemotherapy-refractory acute lymphoblastic leukemia. Sci. Transl. Med. 5, 177ra38. doi: 10.1126/scitranslmed.3005930

Brentjens, R., Yeh, R., Bernal, Y., Riviere, I., and Sadelain, M. (2010). Treatment of chronic lymphocytic leukemia with genetically targeted autologous $\mathrm{T}$ cells: case report of an unforeseen adverse event in a phase I clinical trial. Mol. Ther. 18, 666-668. doi: 10.1038/mt.2010.31

Budde, L. E., Berger, C., Lin, Y., Wang, J., Lin, X., Frayo, S. E., et al. (2013). Combining a CD20 chimeric antigen receptor and an inducible caspase 9 suicide switch to improve the efficacy and safety of $\mathrm{T}$ cell adoptive immunotherapy for lymphoma. PloS ONE 8:e82742. doi: 10.1371/journal.pone. 0082742

Carlotti, F., Zaldumbide, A., Martin, P., Boulukos, K. E., Hoeben, R. C., and Pognonec, P. (2005). Development of an inducible suicide gene system based on human caspase 8. Cancer Gene Ther. 12, 627-639. doi: 10.1038/sj.cgt. 7700825

Ciceri, F., Bonini, C., Marktel, S., Zappone, E., Servida, P., Bernardi, M., et al. (2007). Antitumor effects of HSV-TK-engineered donor lymphocytes after allogeneic stem-cell transplantation. Blood 109, 4698-4707. doi: 10.1182/blood2006-05-023416

Ciceri, F., Bonini, C., Stanghellini, M. T., Bondanza, A., Traversari, C., Salomoni, M., et al. (2009). Infusion of suicide-gene-engineered donor lymphocytes after family haploidentical haemopoietic stem-cell transplantation for leukaemia (the TK007 trial): a non-randomised phase I-II study. Lancet Oncol. 10, 489-500. doi: 10.1016/S1470-2045(09)70074-9

Cieri, N., Mastaglio, S., Oliveira, G., Casucci, M., Bondanza, A., and Bonini, C. (2014). Adoptive immunotherapy with genetically modified lymphocytes in allogeneic stem cell transplantation. Immunol. Rev. 257, 165-180. doi: 10.1111/imr.12130

Clackson, T., Yang, W., Rozamus, L. W., Hatada, M., Amara, J. F., Rollins, C. T., et al. (1998). Redesigning an FKBP-ligand interface to generate chemical dimerizers with novel specificity. Proc. Natl. Acad. Sci. U.S.A. 95, 10437-10442. doi: 10.1073/pnas.95.18.10437

Clark, A. J., Iwobi, M., Cui, W., Crompton, M., Harold, G., Hobbs, S., et al. (1997). Selective cell ablation in transgenic mice expression E. coli nitroreductase. Gene Ther. 4, 101-110. doi: 10.1038/sj.gt.3300367

Copelan, E. A. (2006). Hematopoietic stem-cell transplantation. N. Engl. J. Med. 354, 1813-1826. doi: 10.1056/NEJMra052638

Davila, M. L., Riviere, I., Wang, X., Bartido, S., Park, J., Curran, K., et al. (2014). Efficacy and toxicity management of $19-28 \mathrm{z}$ CAR $\mathrm{T}$ cell therapy in B cell acute lymphoblastic leukemia. Sci. Transl. Med. 6, 224ra25. doi: 10.1126/scitranslmed.3008226

de Bueger, M., Bakker, A., Van Rood, J. J., Van der Woude, F., and Goulmy, E. (1992). Tissue distribution of human minor histocompatibility antigens. Ubiquitous versus restricted tissue distribution indicates heterogeneity among human cytotoxic T lymphocyte-defined non-MHC antigens. J. Immunol. 149, 1788-1794.

Di Stasi, A., Tey, S. K., Dotti, G., Fujita, Y., Kennedy-Nasser, A., Martinez, C., et al. (2011). Inducible apoptosis as a safety switch for adoptive cell therapy. N. Engl. J. Med. 365, 1673-1683. doi: 10.1056/NEJMoa1106152

Duarte, S., Carle, G., Faneca, H., de Lima, M. C., and Pierrefite-Carle, V. (2012). Suicide gene therapy in cancer: where do we stand now? Cancer Lett. 324, 160-170. doi: 10.1016/j.canlet.2012.05.023

Dudley, M. E., Gross, C. A., Somerville, R. P., Hong, Y., Schaub, N. P., Rosati, S. F., et al. (2013). Randomized selection design trial evaluating CD8+enriched versus unselected tumor-infiltrating lymphocytes for adoptive cell therapy for patients with melanoma. J. Clin. Oncol. 31, 2152-2159. doi: 10.1200/JCO.2012.46.6441

Dudley, M. E., Wunderlich, J. R., Robbins, P. F., Yang, J. C., Hwu, P., Schwartzentruber, D. J., et al. (2002). Cancer regression and autoimmunity in patients after clonal repopulation with antitumor lymphocytes. Science 298, 850-854. doi: 10.1126/science.1076514

Elion, G. B., Furman, P. A., Fyfe, J. A., de Miranda, P., Beauchamp, L., and Schaeffer, H. J. (1977). Selectivity of action of an antiherpetic agent, 9-(2hydroxyethoxymethyl) guanine. Proc. Natl. Acad. Sci. U.S.A. 74, 5716-5720. doi: 10.1073/pnas.74.12.5716 
Evans, G. R. D., and Dey, D. (2011). Suicide Gene Therapy by Herpes Simplex Virus-1 Thymidine Kinase (HSV-TK). Orange, CA: InTech.

Freytag, S. O., Movsas, B., Aref, I., Stricker, H., Peabody, J., Pegg, J., et al. (2007). Phase I trial of replication-competent adenovirus-mediated suicide gene therapy combined with IMRT for prostate cancer. Mol. Ther. 15, 1016-1023. doi: 10.1038/mt.sj.6300120

Freytag, S. O., Stricker, H., Pegg, J., Paielli, D., Pradhan, D. G., Peabody, J., et al. (2003). Phase I study of replication-competent adenovirus-mediated double-suicide gene therapy in combination with conventional-dose threedimensional conformal radiation therapy for the treatment of newly diagnosed, intermediate- to high-risk prostate cancer. Cancer Res. 63, 7497-7506.

Fujimoto, M., Poe, J. C., Inaoki, M., and Tedder, T. F. (1998). CD19 regulates B lymphocyte responses to transmembrane signals. Semin. Immunol. 10, 267-277. doi: 10.1006/smim.1998.9999

Garin, M. I., Garrett, E., Tiberghien, P., Apperley, J. F., Chalmers, D., Melo, J. V., et al. (2001). Molecular mechanism for ganciclovir resistance in human T lymphocytes transduced with retroviral vectors carrying the herpes simplex virus thymidine kinase gene. Blood 97, 122-129. doi: 10.1182/blood.V97.1.122

Griffioen, M., van Egmond, E. H., Kester, M. G., Willemze, R., Falkenburg, J. H., and Heemskerk, M. H. (2009). Retroviral transfer of human CD20 as a suicide gene for adoptive T-cell therapy. Haematologica 94, 1316-1320. doi: 10.3324/haematol.2008.001677

Grupp, S. A., Kalos, M., Barrett, D., Aplenc, R., Porter, D. L., Rheingold, S. R., et al. (2013). Chimeric antigen receptor-modified $\mathrm{T}$ cells for acute lymphoid leukemia. N. Engl. J. Med. 368, 1509-1518. doi: 10.1056/NEJMoa1215134

Hewitt, Z., Priddle, H., Thomson, A. J., Wojtacha, D., and McWhir, J. (2007). Ablation of undifferentiated human embryonic stem cells: exploiting innate immunity against the Gal alpha1-3Galbeta1-4GlcNAc-R (alpha-Gal) epitope. Stem Cells 25, 10-18. doi: 10.1634/stemcells.2005-0481

Hodish, I., Tal, R., Shaish, A., Varda-Bloom, N., Greenberger, S., Rauchwerger, A., et al. (2009). Systemic administration of radiation-potentiated anti-angiogenic gene therapy against primary and metastatic cancer based on transcriptionally controlled HSV-TK. Cancer Biol. Ther. 8, 424-432. doi: 10.4161/cbt.8.5.7589

Hoyos, V., Savoldo, B., Quintarelli, C., Mahendravada, A., Zhang, M., Vera, J., et al. (2010). Engineering CD19-specific T lymphocytes with interleukin-15 and a suicide gene to enhance their anti-lymphoma/leukemia effects and safety Leukemia 24, 1160-1170. doi: 10.1038/leu.2010.75

Huber, B. E., Richards, C. A., and Krenitsky, T. A. (1991). Retroviral-mediated gene therapy for the treatment of hepatocellular carcinoma: an innovative approach for cancer therapy. Proc. Natl. Acad. Sci. U.S.A. 88, 8039-8043. doi: 10.1073/pnas.88.18.8039

Introna, M., Barbui, A. M., Bambacioni, F., Casati, C., Gaipa, G., Borleri, G., et al. (2000). Genetic modification of human T cells with CD20: a strategy to purify and lyse transduced cells with anti-CD20 antibodies. Hum. Gene Ther. 11, 611-620. doi: 10.1089/10430340050015798

Iuliucci, J. D., Oliver, S. D., Morley, S., Ward, C., Ward, J., Dalgarno, D., et al. (2001). Intravenous safety and pharmacokinetics of a novel dimerizer drug, AP1903, in healthy volunteers. J. Clin. Pharmacol. 41, 870-879. doi: 10.1177/00912700122010771

Johnson, L. A., Morgan, R. A., Dudley, M. E., Cassard, L., Yang, J. C., Hughes, M. S., et al. (2009). Gene therapy with human and mouse T-cell receptors mediates cancer regression and targets normal tissues expressing cognate antigen. Blood 114, 535-546. doi: 10.1182/blood-2009-03-211714

Kaur, B., Cripe, T. P., and Chiocca, E. A. (2009). "Buy one get one free": armed viruses for the treatment of cancer cells and their microenvironment. Curr. Gene Ther. 9, 341-355. doi: 10.2174/156652309789753329

Kieback, E., Charo, J., Sommermeyer, D., Blankenstein, T., and Uckert, W. (2008). A safeguard eliminates $\mathrm{T}$ cell receptor gene-modified autoreactive T cells after adoptive transfer. Proc. Natl. Acad. Sci. U.S.A. 105, 623-628. doi: 10.1073/pnas.0710198105

Kochenderfer, J. N., Dudley, M. E., Feldman, S. A., Wilson, W. H., Spaner, D. E., Maric, I., et al. (2012). B-cell depletion and remissions of malignancy along with cytokine-associated toxicity in a clinical trial of anti-CD19 chimeric-antigenreceptor-transduced T cells. Blood 119, 2709-2720. doi: 10.1182/blood-201110-384388

Lamers, C. H., Sleijfer, S., van Steenbergen, S., van Elzakker, P., van Krimpen, B., Groot, C., et al. (2013). Treatment of metastatic renal cell carcinoma with CAIX CAR-engineered T cells: clinical evaluation and management of on-target toxicity. Mol. Ther. 21, 904-912. doi: 10.1038/mt.2013.17
Lamers, C. H., Sleijfer, S., Vulto, A. G., Kruit, W. H., Kliffen, M., Debets, R., et al. (2006). Treatment of metastatic renal cell carcinoma with autologous Tlymphocytes genetically retargeted against carbonic anhydrase IX: first clinical experience. J. Clin. Oncol. 24, e20-e22. doi: 10.1200/JCO.2006.05.9964

Li, M., Suzuki, K., Kim, N. Y., Liu, G. H., and Izpisua Belmonte, J. C. (2014). A cut above the rest: targeted genome editing technologies in human pluripotent stem cells. J. Biol. Chem. 289, 4594-4599. doi: 10.1074/jbc.R113. 488247

Li, N., Zhou, J., Weng, D., Zhang, C., Li, L., Wang, B., et al. (2007). Adjuvant adenovirus-mediated delivery of herpes simplex virus thymidine kinase administration improves outcome of liver transplantation in patients with advanced hepatocellular carcinoma. Clin. Cancer Res. 13, 5847-5854. doi: 10.1158/10780432.CCR-07-0499

Linette, G. P., Stadtmauer, E. A., Maus, M. V., Rapoport, A. P., Levine, B. L., Emery, L., et al. (2013). Cardiovascular toxicity and titin cross-reactivity of affinity-enhanced T cells in myeloma and melanoma. Blood 122, 863-871. doi: 10.1182/blood-2013-03-490565

MacCorkle, R. A., Freeman, K. W., and Spencer, D. M. (1998). Synthetic activation of caspases: artificial death switches. Proc. Natl. Acad. Sci. U.S.A. 95, 3655-3660. doi: 10.1073/pnas.95.7.3655

Marin, V., Cribioli, E., Philip, B., Tettamanti, S., Pizzitola, I., Biondi, A., et al. (2012). Comparison of different suicide-gene strategies for the safety improvement of genetically manipulated T cells. Hum. Gene Ther. Methods 23, 376-386. doi: 10.1089/hgtb.2012.050

Mazor, R., Vassall, A. N., Eberle, J. A., Beers, R., Weldon, J. E., Venzon, D. J., et al. (2012). Identification and elimination of an immunodominant T-cell epitope in recombinant immunotoxins based on Pseudomonas exotoxin A. Proc. Natl. Acad. Sci. U.S.A. 109, E3597-E3603. doi: 10.1073/pnas.1218138109

Meadows, L., Wang, W., den Haan, J. M., Blokland, E., Reinhardus, C., Drijfhout, J. W., et al. (1997). The HLA-A ${ }^{\star} 0201$-restricted H-Y antigen contains a posttranslationally modified cysteine that significantly affects $\mathrm{T}$ cell recognition. Immunity 6, 273-281. doi: 10.1016/S1074-7613(00)80330-1

Molldrem, J. J., Lee, P. P., Kant, S., Wieder, E., Jiang, W., Lu, S., et al. (2003). Chronic myelogenous leukemia shapes host immunity by selective deletion of high-avidity leukemia-specific T cells. J. Clin. Invest. 111, 639-647. doi: 10.1172/JCI200316398

Moolten, F. L. (1986). Tumor chemosensitivity conferred by inserted herpes thymidine kinase genes: paradigm for a prospective cancer control strategy. Cancer Res. 46, 5276-5281.

Morgan, R. A., Chinnasamy, N., Abate-Daga, D., Gros, A., Robbins, P. F., Zheng, Z., et al. (2013). Cancer regression and neurological toxicity following anti-MAGE-A3 TCR gene therapy. J. Immunother. 36, 133-151. doi: 10.1097/CJI.0b013e3182829903

Morgan, R. A., Yang, J. C., Kitano, M., Dudley, M. E., Laurencot, C. M., and Rosenberg, S. A. (2010). Case report of a serious adverse event following the administration of $\mathrm{T}$ cells transduced with a chimeric antigen receptor recognizing ERBB2. Mol. Ther. 18, 843-851. doi: 10.1038/mt.2010.24

Mukherjee, S., and Thrasher, A. J. (2013). Gene therapy for PIDs: progress, pitfalls and prospects. Gene 525, 174-181. doi: 10.1016/j.gene.2013.03.098

Nakayama, K., Pergolizzi, R. G., and Crystal, R. G. (2005). Gene transfer-mediated pre-mRNA segmental trans-splicing as a strategy to deliver intracellular toxins for cancer therapy. Cancer Res. 65, 254-263.

Narsinh, K., Narsinh, K. H., and Wu, J. C. (2011). Derivation of human induced pluripotent stem cells for cardiovascular disease modeling. Cir. Res. 108, 1146-1156. doi: 10.1161/CIRCRESAHA.111.240374

Nemunaitis, J., Cunningham, C., Senzer, N., Kuhn, J., Cramm, J., Litz, C., et al. (2003). Pilot trial of genetically modified, attenuated Salmonella expressing the E. coli cytosine deaminase gene in refractory cancer patients. Cancer Gene Ther. 10, 737-744. doi: 10.1038/sj.cgt.7700634

Nor, J. E., Hu, Y., Song, W., Spencer, D. M., and Nunez, G. (2002). Ablation of microvessels in vivo upon dimerization of iCaspase-9. Gene Ther. 9, 444-451. doi: $10.1038 /$ sj.gt.3301671

Oliveira, G., Greco, R., Lupo-Stanghellini, M. T., Vago, L., and Bonini, C. (2012) Use of TK-cells in haploidentical hematopoietic stem cell transplantation. Curr. Opin. Hematol. 19, 427-433. doi: 10.1097/MOH.0b013e32835822f5

Pandha, H. S., Martin, L. A., Rigg, A., Hurst, H. C., Stamp, G. W., Sikora, K., et al. (1999). Genetic prodrug activation therapy for breast cancer: a phase I clinical trial of erbB-2-directed suicide gene expression. J. Clin. Oncol. 17, 2180-2189. 
Parkhurst, M. R., Yang, J. C., Langan, R. C., Dudley, M. E., Nathan, D. A., Feldman, S. A., et al. (2011). T cells targeting carcinoembryonic antigen can mediate regression of metastatic colorectal cancer but induce severe transient colitis. Mol. Ther. 19, 620-626. doi: 10.1038/mt.2010.272

Philip, B., Kokalaki, E., Mekkaoui, L., Thomas, S., Straathof, K., Flutter, B., et al. (2014). A highly compact epitope-based marker/suicide gene for easier and safer T-cell therapy. Blood 124, 1277-1287. doi: 10.1182/blood-2014-01-545020

Porter, D. L., Levine, B. L., Kalos, M., Bagg, A., and June, C. H. (2011). Chimeric antigen receptor-modified T cells in chronic lymphoid leukemia. N. Engl. J. Med. 365, 725-733. doi: 10.1056/NEJMoa1 103849

Rezvani, K., Brenchley, J. M., Price, D. A., Kilical, Y., Gostick, E., Sewell, A. K., et al. (2005). T-cell responses directed against multiple HLA-A*0201-restricted epitopes derived from Wilms' tumor 1 protein in patients with leukemia and healthy donors: identification, quantification, and characterization. Clin. Cancer Res. 11, 8799-8807. doi: 10.1158/1078-0432.CCR-05-1314

Rezvani, K., Price, D. A., Brenchley, J. M., Kilical, Y., Gostick, E., Sconocchia, G., et al. (2007). Transfer of PR1-specific T-cell clones from donor to recipient by stem cell transplantation and association with GvL activity. Cytotherapy 9, 245-251. doi: 10.1080/14653240701218524

Robbins, P. F., Morgan, R. A., Feldman, S. A., Yang, J. C., Sherry, R. M., Dudley, M. E., et al. (2011). Tumor regression in patients with metastatic synovial cell sarcoma and melanoma using genetically engineered lymphocytes reactive with NY-ESO-1. J. Clin. Oncol. 29, 917-924. doi: 10.1200/JCO.2010. 32.2537

Serafini, M., Manganini, M., Borleri, G., Bonamino, M., Imberti, L., Biondi, A., et al. (2004). Characterization of CD20-transduced T lymphocytes as an alternative suicide gene therapy approach for the treatment of graftversus-host disease. Hum. Gene Ther. 15, 63-76. doi: 10.1089/104303404607 32463

Spencer, D. M., Belshaw, P. J., Chen, L., Ho, S. N., Randazzo, F., Crabtree, G. R., et al. (1996). Functional analysis of Fas signaling in vivo using synthetic inducers of dimerization. Curr. Biol. 6, 839-847. doi: 10.1016/S0960-9822(02)00607-3

Spencer, D. M., Wandless, T. J., Schreiber, S. L., and Crabtree, G. R. (1993). Controlling signal transduction with synthetic ligands. Science 262, 1019-1024. doi: 10.1126/science.7694365

Springer, C. J., and Niculescu-Duvaz, I. (2000). Prodrug-activating systems in suicide gene therapy. J. Clin. Invest. 105, 1161-1167. doi: 10.1172/JCI10001

Straathof, K. C., Pule, M. A., Yotnda, P., Dotti, G., Vanin, E. F., Brenner, M. K., et al. (2005). An inducible caspase 9 safety switch for T-cell therapy. Blood 105, 4247-4254. doi: 10.1182/blood-2004-11-4564

Tey, S.-K. (2014). Adoptive T-cell therapy: adverse events and safety switches. Clin. Transl. Immunol. 3:e17. doi: 10.1038/cti.2014.11

Tey, S. K., Dotti, G., Rooney, C. M., Heslop, H. E., and Brenner, M. K. (2007) Inducible caspase 9 suicide gene to improve the safety of allodepleted T cells after haploidentical stem cell transplantation. Biol. Blood Marrow Transplant. 13, 913-924. doi: 10.1016/j.bbmt.2007.04.005

Tiberghien, P., Ferrand, C., Lioure, B., Milpied, N., Angonin, R., Deconinck, E., et al. (2001). Administration of herpes simplex-thymidine kinase-expressing donor T cells with a T-cell-depleted allogeneic marrow graft. Blood 97, 63-72. doi: 10.1182/blood.V97.1.63

Tiraby, M., Cazaux, C., Baron, M., Drocourt, D., Reynes, J. P., and Tiraby, G. (1998). Concomitant expression of E. coli cytosine deaminase and uracil phosphoribosyltransferase improves the cytotoxicity of 5-fluorocytosine. FEMS Microbiol. Lett. 167, 41-49. doi: 10.1111/j.1574-6968.1998.tb13205.x

Traversari, C., Marktel, S., Magnani, Z., Mangia, P., Russo, V., Ciceri, F., et al. (2007). The potential immunogenicity of the TK suicide gene does not prevent full clinical benefit associated with the use of TK-transduced donor lymphocytes in HSCT for hematologic malignancies. Blood 109, 4708-4715. doi: 10.1182/blood-2006-04-015230
Vago, L., Oliveira, G., Bondanza, A., Noviello, M., Soldati, C., Ghio, D., et al. (2012). T-cell suicide gene therapy prompts thymic renewal in adults after hematopoietic stem cell transplantation. Blood 120, 1820-1830. doi: 10.1182/blood-201201-405670

Vago, L., Perna, S. K., Zanussi, M., Mazzi, B., Barlassina, C., Stanghellini, M. T., et al. (2009). Loss of mismatched HLA in leukemia after stem-cell transplantation. N. Engl. J. Med. 361, 478-488. doi: 10.1056/NEJMoa0811036

Voges, J., Reszka, R., Gossmann, A., Dittmar, C., Richter, R., Garlip, G., et al. (2003). Imaging-guided convection-enhanced delivery and gene therapy of glioblastoma. Ann. Neurol. 54, 479-487. doi: 10.1002/ana.10688

Vogt, M. H., de Paus, R. A., Voogt, P. J., Willemze, R., and Falkenburg, J. H. (2000). DFFRY codes for a new human male-specific minor transplantation antigen involved in bone marrow graft rejection. Blood 95, 1100-1105.

Wang, W., Meadows, L. R., den Haan, J. M., Sherman, N. E., Chen, Y., Blokland, E., et al. (1995). Human H-Y: a male-specific histocompatibility antigen derived from the SMCY protein. Science 269, 1588-1590. doi: 10.1126/science. 7667640

Wang, X., Chang, W. C., Wong, C. W., Colcher, D., Sherman, M., Ostberg, J. R., et al. (2011). A transgene-encoded cell surface polypeptide for selection, in vivo tracking, and ablation of engineered cells. Blood 118, 1255-1263. doi: 10.1182/blood-2011-02-337360

Xu, F., Li, S., Li, X. L., Guo, Y., Zou, B. Y., Xu, R., et al. (2009). Phase I and biodistribution study of recombinant adenovirus vector-mediated herpes simplex virus thymidine kinase gene and ganciclovir administration in patients with head and neck cancer and other malignant tumors. Cancer Gene Ther. 16, 723-730. doi: 10.1038/cgt.2009.19

Yamabe, K., Shimizu, S., Ito, T., Yoshioka, Y., Nomura, M., Narita, M., et al. (1999). Cancer gene therapy using a pro-apoptotic gene, caspase-3. Gene Ther. 6, 1952-1959. doi: 10.1038/sj.gt.3301041

Yee, C., Thompson, J. A., Roche, P., Byrd, D. R., Lee, P. P., Piepkorn, M., et al. (2000). Melanocyte destruction after antigen-specific immunotherapy of melanoma: direct evidence of t cell-mediated vitiligo. J. Exp. Med. 192, 1637-1644. doi: 10.1084/jem.192.11.1637

Zhou, L. J., Ord, D. C., Hughes, A. L., and Tedder, T. F. (1991). Structure and domain organization of the CD19 antigen of human, mouse, and guinea pig B lymphocytes. Conservation of the extensive cytoplasmic domain. J. Immunol. 147, 1424-1432.

Zhou, X., Di Stasi, A., Tey, S. K., Krance, R. A., Martinez, C., Leung, K. S., et al. (2014). Long-term outcome after haploidentical stem cell transplant and infusion of $\mathrm{T}$ cells expressing the inducible caspase 9 safety transgene. Blood 123, 3895-3905. doi: 10.1182/blood-2014-01-551671

Conflict of Interest Statement: The authors declare that the research was conducted in the absence of any commercial or financial relationships that could be construed as a potential conflict of interest.

Received: 28 August 2014; accepted: 31 October 2014; published online: 27 November 2014.

Citation: Jones BS, Lamb LS, Goldman F and Di Stasi A (2014) Improving the safety of cell therapy products by suicide gene transfer. Front. Pharmacol. 5:254. doi: 10.3389/ fphar.2014.00254

This article was submitted to Experimental Pharmacology and Drug Discovery, a section of the journal Frontiers in Pharmacology.

Copyright (C) 2014 Jones, Lamb, Goldman and Di Stasi. This is an open-access article distributed under the terms of the Creative Commons Attribution License (CC BY). The use, distribution or reproduction in other forums is permitted, provided the original author(s) or licensor are credited and that the original publication in this journal is cited, in accordance with accepted academic practice. No use, distribution or reproduction is permitted which does not comply with these terms. 